\title{
Neosporose bovina: estudo de fatores de risco em 60 propriedades leiteras no estado do Rio Grande do Sul e levantamento de causas de aborto bovino com ênfase em Neospora caninum*
}

\author{
LUÍS GUSTAVO CORBELLINI \\ David Driemeier (Orientador - UFRGS) \\ David Smith (Co-orientador - University of Nebraska)
}

Banca: Neusa Saltiel Stobbe (UFRGS), Claudio Severo Lombardo de Barros (UFSM), Elmiro Rosendo do Nascimento (UFF)

\begin{abstract}
O estudo resultou em dois artigos principais relacionados à neosporose bovina e um relato de casos de aborto micótico em bovinos. O primeiro artigo trata de fatores de risco associados à infecção por Neospora caninum em propriedades leiteiras no estado do Rio Grande do sul e o segundo refere-se a um levantamento de causas de aborto bovino com ênfase em neosporose. Um estudo transversal foi realizado para verificar a associação entre fatores de risco e soroprevalência de $N$. caninum em 60 propriedades leiteiras escolhidas aleatoreamente em duas regiões distintas (Ibirubá e Pelotas/São Lourenço do Sul). Um questionário relativo à transmissão de $N$. caninum foi aplicado nas propriedades. Coletou-se sangue de $40 \%$ dos animais de cada propriedade para realização do teste de imunofluorescência indireta (IFI). A associação entre os fatores de risco e soroprevalência foi analisada através da estimação da equação generalizada com função logística multivariada. Amostras de sangue foram coletadas de 1549/ 3872 animais. A soroprevalência geral encontrada nos animais foi de 17,8\% (276/1549), sendo que 93,3\% (56/60) dos rebanhos apresentavam pelo menos um animal soropositivo. Foram encontradas quatro variáveis associadas significativamente com a soroprevalência de $N$. caninum: número de cães ( $\mathrm{P}=0,02 ; \mathrm{OR} 1,17)$, área em hectares ( $(\mathrm{P}=0.01 ; \mathrm{OR} 0,90)$, alimentação de bezerros com "pool"de colostro $(\mathrm{P}=0,003$; OR 2,07) e região $(\mathrm{P}=0,03$; OR 0,65$)$. No segundo artigo, 161 fetos bovinos abortados foram analisados em 1,5 anos. A causa de aborto foi identificada em 51,5\% dos casos. Infecção por $N$. caninum foi observada em $23 \%$ dos fetos. Aborto bacteriano foi diagnosticado em 17,4\% dos casos (28/161), seguido por infecção micótica (3,1\%) e viral (3,1\%). Casos de aborto causado por Aspergillus sp. em bovinos foram descritos em detalhe no terceiro artigo, onde cinco de 147 (3,4\%) dos fetos analisados apresentavam lesões macroscópicas e/ou histológicas caracterizadas basicamente por placentite ou hepatite necrozante e pneumonia supurativa.
\end{abstract}

Descritores: Neospora caninum, aborto bovino, fatores de risco, doenças da reprodução. 


\title{
Bovine neosporosis: risk factor associated with Neospora caninum seroprevalence in $\mathbf{6 0}$ dairy farms in southern Brazil and diagnostic survey of bovine abortion with special reference to Neospora caninum infection ${ }^{* *}$
}

\author{
LUÍS GUSTAVO CORBELLINI
}

David Driemeier (Adviser - UFRGS)

David Smith (Co-Adviser - University of Nebraska)

Committee: Neusa Saltiel Stobbe (UFRGS), Claudio Severo Lombardo de Barros (UFSM), Elmiro Rosendo do Nascimento (UFF)

\begin{abstract}
This study resulted in two main articles on bovine neosporosis and a third article describing bovine mycotic abortion. The first article describes risk factors for Neospora caninum seroprevalence in dairy farms in Southern Brazil while the second one reports diagnosis of bovine abortion with special emphasis on $N$. caninum infection. A cross-sectional study was used to test the relationship between herd seroprevalence to $N$. caninum and various potential herd-level risk factors in 60 randomly selected dairy farms located in two distinct regions in the State of Rio Grande do Sul. A questionnaire was designed to summarize each farm's production system as it might relate to N. caninum transmission. Serum samples were collected from $40 \%$ of animals in each farm and $N$. caninum antibodies were detected by immunofluorescent antibody test (IFAT). The association between potential risk-factors and the probability of an animal being seropositive was modeled using a generalized estimation equations (GEE) logistic regression model. Blood samples were collected from 1,549 out of 3,872 animals (40\%). N. caninum seroprevalence was $17.8 \%$. Overall, $93.3 \%$ of herds $(56 / 60)$ had at least one seropositive animal identified. In the final multivariable model, four variables were significantly associated with $N$. caninum sero-response: the number of dogs on the farm $(\mathrm{P}=0.02 ; \mathrm{OR} 1.17)$, farm area in hectares $(\mathrm{P}=0.01$; OR 0.90), feeding pooled sources of colostrum $(\mathrm{P}=0.003$; OR 2.07), and region $(\mathrm{P}=0.03$; $\mathrm{OR} 0.65)$. In the second article, 161 bovine aborted fetuses were analyzed during a 1.5 year period. The cause of abortion was identified in $51.5 \%$ of cases. Overall, $23 \%$ (37/161) of the fetuses were considered to be infected with $N$. caninum. Bacterial infection accounted for $17.4 \%$ (28/161) of cases, fungal infection for 3.1\% (5/161) of cases and viral etiology for 1.8\% (3/161). Bovine abortion caused by Aspergillus sp. is described in detail in the third article, in which 5/147 (3.4\%) fetuses had gross and/or histologic lesions of necrotizing placentitis and/or hepatitis and suppurative bronchopneumonia.
\end{abstract}

Key words: Neospora caninum, bovine abortion, risk factors, reproductive diseases. 